This is the accepted manuscript of the article, which has been published in Aatsinki U., Annola J. \& Kaarninen M. (eds) Families, Values, and the Transfer of Knowledge in Northern Societies, 1500-2000. New York: Routledge. Routledge Studies in Cultural History no. 66. ISBN: 978-0-367-07757-0. http://dx.doi.org/10.4324/9780429022623

\title{
A Place in the Sun?
}

\section{Education as a Middle-Class Family Value in Nineteenth-Century Finland}

\author{
Johanna Annola \\ Tampere University
}

\section{Introduction}

This chapter discusses education as a central value in the life of one family in the Grand Duchy of Finland at the end of the nineteenth century. By analysing the life and choices of a widowed mother and her son, the chapter sheds light on the role of education as a means of social differentiation in a modernising society.

In this chapter, social differentiation is connected to the birth of new intermediate social groups - the middle classes - that emerged in Western European societies in the wake of industrialisation, urbanisation, professionalisation, democratisation, and the rise of meritocracy from the eighteenth century onwards (Blackbourn 1991; Kocka 1993). In this context, Finland was a latecomer: the boundaries of the Finnish middle class were still undefined in the late nineteenth century, which provided the members of the above-mentioned family and their contemporaries with opportunities for social advancement into and within this emerging middle class.

The new middle class was not a homogeneous entity. In terms of social differentiation within the Finnish middle class, the most crucial factor was education. While the lower strata of the Finnish middle class consisted of prosperous freeholder peasants, artisans, the petty bourgeoisie of the cities, and lower-ranking white-collar employees, the upper layer of the middle class was composed of wealthier entrepreneurs and individuals with higher education: grammar school teachers, doctors, lawyers, priests, and upper-ranking officials (Haapala 1995, 97-122). 
In earlier research, the educated upper strata of the Finnish middle class is referred to as the rising intelligentsia. This group was 'rising' in relation to the old aristocratic elite, a Swedish-speaking group with roots dating to the Swedish period of Finland's history (Häggman 1994). The emergence of the rising intelligentsia indicates that the socio-economic importance of education and professionalisation was increasing in society: the members of the rising intelligentsia were able to acquire prominent positions in society despite not being part of the old elite. They served as officials in municipal administration and as civil servants in state administration, they held central offices within the Evangelical Lutheran state church and the developing school system, and they became the leading members of large voluntary associations. By the early twentieth century, the rising intelligentsia had become an influential group in Finnish society (Haapala 1995, 104).

The developments in Finland differed from those generally manifesting in Eastern Europe, for example. Jürgen Kocka (1993, 23-24) has pointed out that education was not given particular prominence in Eastern Europe, because educated people generally had no access to the higher levels of administration due to foreign domination. However, as a Grand Duchy within Imperial Russia, Finland had a relatively extensive autonomous status with a central administration, a state church, and a school system of its own. As there were prominent positions available within the Finnish institutions, having a good education was considered desirable, especially in the middle strata of society. This, in turn, accelerated the emergence of modern meritocracy in Finland.

In their article on intergenerational social mobility in nineteenth-century Sweden, Ineke Maas and Marco van Leeuwen have suggested that the growing importance of education in society led to better opportunities for upper-class social groups to secure their hold on privileged positions (Maas and van Leeuwen 2002, 191). In Finland, the relationship between meritocracy and economic prosperity was crystallised in the way grammar schools became one of the gateways for the rising intelligentsia.

In most cases, the members of the rising intelligentsia received their professional qualifications at the Imperial Alexander University in Helsinki, which was the only university in the Grand Duchy. In order be admitted to the university, one had to pass a matriculation examination. That, in turn, usually required a grammar school education. For most parents, putting their offspring into a grammar school was a significant financial investment. Money was needed for tuition fees, school books, and suitable clothing. Moreover, as all grammar schools were located in cities, pupils attending from rural areas had to rent accommodation for the school year. As such, grammar schools remained the privilege of 
a chosen few: as late as 1910, only seven per cent of the applicable age cohort entered a grammar school (Haapala 1995, 39).

Thus, for the rising intelligentsia, education was one means of distinguishing itself from the uneducated masses, who were considered brutal and simple. In addition, the rising intelligentsia sought to set itself apart from the old elite, which was regarded as old-fashioned and corrupt (Häggman 1994, 23-26). The desire to make this distinction was present in the social networking of the rising intelligentsia, as well as in the common values, ideologies, and traditions shared via these networks.

Pierre Bourdieu (1984) refers to education as cultural capital, and social networking and shared values as social capital. These two forms of capital were interlinked: in order to maximise the benefits of having a good education, an individual was expected to make use of his/her social networks. In order to avoid intergenerational downward social mobility, he or she was expected to transfer the accumulated capital to the next generation (Häkkinen 2014, 31; Roos 1987).

The social capital of Finland's rising intelligentsia resembled that of the German Bildungsbürgertum, the educated upper stratum of the German middle class. The Bildungsbürgertum sought to make a distinction vis-à-vis both the lower social strata and the old elite by employing a specific set of values, which included respect for scholarly pursuits, a positive attitude towards regular work and achievement, a propensity towards a rational lifestyle, a specific ideal of family life, and a specific appreciation of music, literature, and the arts (Kocka 1993, 6-8). These values were pivotal to Finland's rising intelligentsia as well.

Moreover, Bildungsbürgertum gave rise to the idea of the German nation (Blackbourn 1991, 2-3). Similarly, the majority of Finland's rising intelligentsia found its ideological home among the ranks of the nationalistic Fennoman movement. The roots of the movement were grounded in the perceived division between the old Swedish-speaking elite and the Finnish-speaking majority. The main objective of the movement was to improve the status of Finnish as the language of administration, education, and culture - and eventually to replace the old elite with a new, Finnish-speaking one. The language question was inseparable from the question of societal hegemony, which is why the Fennoman ideology appealed to the rising intelligentsia. The nationalistic movement provided the 
new group with the collective identity and shared world-view it otherwise lacked (Sulkunen 2004, 214-215).

The chief protagonists of this chapter are the widow of a city treasurer, Hanna Tamminen (b. 1854), and her eldest son, Yrjö Tamminen (b. 1882). They lived in Mikkeli, a small town in south-eastern Finland. I argue that although the family had their roots among freeholder peasants, they were able to advance into the ranks of the rising intelligentsia by accumulating cultural and social capital over three consecutive generations. The process was initiated by Hanna's father Emanuel Hagelin, who cut loose from the traditional setting of his family by becoming a cantor and organist and allowing his daughter to attend the prominent Antell School for Girls in Mikkeli (Antell 1905, 87, 98; Jyväskylä Birth Records 1796-1832; Kuujo 1971, 393-397, 399; Mikkeli Communion Book 1859_ 1869). In 1878, Hanna married Juho Tamminen (b. 1843), a farmer's son who had attended grammar school for four years (JLSA 1983, 87; Luhanka Children's Book 1839-1857). Thus, their marriage was a union of two individuals with a similar social status. ${ }^{1}$

Having a more extensive education than most of their contemporaries, the young couple stood on the threshold of the rising intelligentsia. However, their social status was ambivalent because Juho did not have a university degree, which was usually required for higher administrative offices. He had to find white-collar posts with unspecified qualifications: he worked as a deputy master at a workhouse, as a self-employed attorney ${ }^{2}$, as a clerk at the Mikkeli County Administration, and from 1881 onwards as treasurer of Mikkeli City (Mikkeli City Treasury 1882; Helsingfors Dagblad 1881; Hämäläinen 1881; Mikkeli City Council 1880, 1881; Pellervo 1881a-b; 1882a-b; Vilkuna 1992, 245). In order to pass as members of the rising intelligentsia, the Tamminens had to both integrate into the right networks in the city and invest in their children's grammar school education. ${ }^{3}$

The chapter concentrates on the period of 1887-1900, which can be regarded as critical vis-à-vis the development of the social status of the family. Firstly, I analyse how Hanna Tamminen's commitment to her children's education was manifested after the death of her husband in 1887. Secondly, I reveal how education as a family value was interwoven into the life and thought of her son, who matriculated at the Imperial Alexander University in 1900 (MLSA 1948, 478; Student Register 1817-1901). These questions are linked to a discussion of how the family tried to maximise its cultural capital by investing in social capital, such as the local networks of the rising intelligentsia and the habits typical of these networks. 
Why select the life and choices of an ordinary middle-class family in the Grand Duchy of Finland as a subject of study? As Toril Moi (1999) has suggested, social capital is above all a matter of personal relations, which are variable and often contradictory by nature. The analysis 'cannot remain on the level of generalities: it must engage with specific social institutions and practices, and it must show precisely how these factors influence' (295) the choices and strategies of the individual. Therefore, it seems necessary to put the individual at the centre of research. Previously, Finnish research on middle-class individuals (e.g. Ala 1999; Jalava 2005; Juvonen 1995; Leskelä-Kärki 2006; Ollila 1998; Sulkunen 1995; Vares 2005) has largely concentrated on politicians, writers, artists, and association activists who achieved popularity in their own time. In order to shed light on the heterogeneity of the Finnish middle class, more research is needed on ordinary people and especially individuals who invested in social climbing within the middle class. ${ }^{4}$

By discussing the lives of these individuals, it is possible to analyse the relationship between the structural preconditions for social advancement and the above-mentioned middle-class values that were used to support individual aspirations with regard to accumulating cultural and social capital. What makes the Finnish case particularly interesting is the pervasiveness of nationalistic ideology. I suggest that the method of legitimising individual aspirations with nationalistic ideology was typical not only of politicians, writers, artists, and association activists, but also of ordinary middle-class people such as the Tamminens.

The life of the Tamminen family is analysed, firstly, through official documents and records kept by both secular and ecclesiastical authorities: communion books, census lists, and archival materials of the Mikkeli city administration and state poor relief officials. Contemporary newspapers and periodicals are also used where applicable. Secondly, the picture of the family is enhanced by analysing private material, such as diary entries written by Yrjö Tamminen in 1897-1900 and a series of discussions with Yrjö Tamminen's daughter. ${ }^{5}$

The entries from Yrjö Tamminen's diary offer a rare view into the thoughts and networks of a small town grammar school boy. According to Eva Helen Ulvros (1996, 23-26, 32-33. See also Bloom 1996, 24-25; Makkonen 1999, 421; Leskelä-Kärki 2006, 422-426), letters and diaries were not necessarily regarded as private in the nineteenth century. Rather, they were easily shared with friends and family members. Yrjö's diaries were not entirely private either: he was in the habit of exchanging 
diaries with one of his friends on a regular basis. Moreover, he was also aware of the possibility that in the near or far future, a random person might read the diary entries. Although Yrjö did not like the latter prospect, he nevertheless took the trouble of contextualising some of the events he described in order to make them more understandable to the unknown reader. Obviously, the entries are not a window to his thoughts as they were but rather a way of finding out what things he regarded as both important and appropriate enough to be mentioned in a text that was bound to fall into other people's hands.

\section{An investment in education}

Upon widowhood, Hanna Tamminen bore the sole responsibility for taking care of her three children, who were all minors at the time. This section discusses the practical arrangements Hanna made in order to preserve the cultural and social capital the family had accumulated over the preceding years. In order to put Hanna's proceedings into a wider context, it is necessary to first look at the life of the family prior to the death of her husband.

As a Finnish-speaking family of modest origins, the Tamminens did not belong to the old elite of Mikkeli. ${ }^{6}$ However, because of their relatively high level of education and Juho's position in the city administration, they could not be counted among the common people either. During the period of 1878-1887, the family sought to integrate into a new kind of social network - the rising intelligentsia of Mikkeli. This network was partly attached to the old elite, but also partly independent of it, especially when it came to nationalistic Fennoman activities.

It is likely that the integration process was eased by the fact that Hanna had lived in the city for twenty years as the daughter of a respected cantor and as a pupil of the most prominent girls' school in town. The school was originally intended for the daughters of the Swedish-speaking elite, but Finnishspeaking girls like Hanna were also admitted to make up the numbers (Kuujo 1971, 304, 369; Tamminen 2007a). The Swedish school provided her with the ability to cross the local language barrier. As such, she became the perfect passport into the local community for her husband, who was a newcomer to the city. ${ }^{7}$

Becoming a part of the network of the rising intelligentsia meant acquiring a certain lifestyle and the habits typical of it (Ollila 1998, 28-32; Ollila 2000). The Tamminens bought a site downtown, and 
had a lofty house built next to an older building already located on the site (Kuujo 1971, 220; Mikkelin Sanomat 1887, 1889a; Pellervo 1882c). The fact that they were able to employ a maidservant - not to mention the furniture, silverware, bedlinen, and clothing listed in the husband's estate inventory deed - indicate theirs was a relatively prosperous family (Census List 1887; Estate Inventory Deed 1887). It should be noted, however, that the family did not occupy the houses alone: in 1887 , there were three other families living in the houses as lodgers (Census List 1887), which meant extra income from rents.

The Tamminens engaged themselves in numerous local activities for the public good. Juho was a member of the voluntary fire brigade, a board member of the Savings Bank, and the secretary of the Association for Craftsmen and Manufacturers. Moreover, he was the secretary of the City Council from 1884 to 1887 (Mikkeli City Council 1884; Mikkelin Sanomat 1886; Suomalainen Wirallinen Lehti 1884). Hanna held a prominent position among the women of the city: for example, in 1883, she was a member of a committee ${ }^{8}$ that organised a fund-rising lottery for the fire brigade (Pellervo 1883). The actions of the Tamminen couple resonate with Jürgen Kocka's $(1993,7)$ observations on the German Bildungsbürgertum: certain practices of bourgeois culture were associated with having an economically secure life with enough space and time.

Another example of this networking is the Tamminens' relationship with the Krogerus family. The wives had attended the same school in the 1860s (Antell 1905, 86-87). The husbands befriended each other, most likely as they were both working in the county administration in the early 1880s. As the chair of the City Treasury, Mr Krogerus probably had an influence in the appointment of Hanna's husband as the treasurer in 1882 (Mikkeli City Treasury 1881a-b, 1882). It is probable that $\mathrm{Mr}$ Krogerus also acted as a role model to his younger colleague in terms of integrating into the local network: the former was a long-standing member of the very same voluntary associations the latter joined in the 1880s (Mikkelin Sanomat 1889b, 1890). ${ }^{9}$ Moreover, the Krogeruses were godparents of two of the Tamminens' children (Mikkeli Birth Records 1880-1889).

In June 1887, Juho Tamminen was suspended from duty because of irregularities in the city accounts of Mikkeli. He died seven weeks later. After a thorough inspection conducted after Tamminen's death, a deficit was found in the accounts for which he had been responsible (Folkwännen 1887; Mikkeli City Council 1887a-b, 1889). Juho's proceedings cast a dark shadow over both the material and social accomplishments of the family, and it is likely that they were no longer considered as 
aspirational in a positive sense but rather as social climbers in a negative sense. The diary entries of Juho and Hanna's son, Yrjö Tamminen, hint that as a struggling widow, Hanna drifted away from her former network: people were talking ill of the family or abandoning them altogether. 'I know how it feels to hear people scorn your own mother,' Yrjö stated in an entry written on 6 June 1898. In another entry, dated 12 January 1899, he remembered his nanny, whom he referred to as one their 'few true friends' (Diary of Yrjö Tamminen).

The first couple of years as a widow were economically difficult for Hanna, and it became challenging for her to live up to the standards of the rising intelligentsia. She resorted to survival techniques that were typical of poor widowed women both in Finland and in Northern Europe in general at the turn of the nineteenth and twentieth centuries (Moring 2008). Hanna took on more lodgers, which nearly doubled the number of people living in the two Tamminen houses (Census List 1888). Moreover, she turned to needlework, making socks and other woollen garments to order (Mikkelin Sanomat 1888b).

While knitting at home was a relatively easy option for the mother of small children, earning a living from handiwork was hardly considered a suitable occupation for a woman of the rising intelligentsia. Even more humiliating, according to a newspaper advertisement, the orders were to be placed at the Krogerus house (Mikkelin Sanomat 1888b). The arrangement was probably made because Hanna was in danger of losing her own home: the estate of her husband was declared bankrupt in 1888, and the two houses had to be auctioned off the following year (Mikkelin Sanomat 1888a, 1889a).

However, the help from the Krogerus family indicates that the young widow was not completely abandoned, despite the family's decrease in the social capital. Moreover, at the time of the most acute crisis, intrafamilial help proved crucial. At the auction held in 1889, Hanna's father volunteered to buy the two houses, and Hanna's parents moved in with her the same year (Mikkeli Communion Book 1880-1889; Mikkelin Sanomat 1889c). The arrangement provided Hanna with both practical assistance and continuity, which may have contributed to the fact that the family was able to restore some of their social capital as the most acute memory of the scandal faded.

As Yrjö Tamminen turned ten in 1892, the question of entering a grammar school became an urgent one for him. At this point, Hanna had to make the decision of whether to fight for the cultural capital of the family or to give up altogether. Hanna chose the former alternative: it appears she was determined to guarantee her children the same level of education they would have received had their 
father still been alive. Yrjö entered grammar school that year, followed by his sister in 1893 and his younger brother in 1895 (MLSA 1948, 478; MLGSA 1954, 323).

In order to be able to pay for her children's education, Hanna Tamminen took a job as a workhouse matron. Her choice sheds light on the occupational opportunities available to women of the rising intelligentsia and the gendered ideals associated with these occupations.

During the ten years that had passed since Juho Tamminen had worked as the deputy master of a workhouse, the qualifications for workhouse directors had been clarified by the state officials of poor relief. In the 1890s, workhouses were to serve as both shelters for the poor incapable of work and as corrective institutions for the poor capable of work. According to the state officials, the double goal of a workhouse was best achieved if the director was a woman, because care and education were considered feminine pursuits. The most preferable choice was a woman of the rising intelligentsia, because she was likely to share the state officials' understanding of the aims of the workhouse. In practice, women aiming to become workhouse directors were to have at least a basic education (primary school) as well as experience in nursing, mental health nursing, childcare, housekeeping, and bookkeeping (Annola 2011; 2013).

The state officials of poor relief gladly accepted Hanna Tamminen as a workhouse matron, first in Korpilahti in 1892, and then in Janakkala in 1895. What mattered most was her educational background, her experience as the wife of a workhouse master, and the cookery course she had attended in 1892. Her prospects were particularly good because there were few suitable female director candidates available in the early 1890s (Annola 2011, 95). For Hanna, being a workhouse matron became a socially acceptable means of supporting her family. Because the occupation was linked with upper middle-class ideals in Finland, Hanna was able to secure herself a steady income without actually sacrificing her social status as a potential member of the rising intelligentsia (Annola forthcoming).

Hanna's salary at Janakkala workhouse was 600 Finnish marks per year, which was higher than the usual salary of a female director of a small rural workhouse (FWA 1894, 188; Janakkala Parish Council 1896). ${ }^{10}$ In addition, she was allotted private quarters in the workhouse, with free lighting and heating. Consequently, she did not have to pay for her accommodation, and she could keep her children close by - in theory, at least. According to official records, the entire family moved to 
Janakkala in 1897 (Janakkala Communion Book 1896-1905), but the diaries of Yrjö Tamminen show that the children only spent their summers at the workhouse with their mother. Because of their schooling, they were otherwise living in Mikkeli with Hanna's father.

There was nothing unusual about splitting up the family during the school year. By officially moving to Janakkala, the Tamminen children had joined the mass of rural children who needed quarters in order to attend grammar schools in cities. It was customary for rural children to live in the households of their urban relatives during the school year, because it was usually cheaper than renting accommodation on the open market (Ollila 1998, 37).

The arrangement was exceptionally favourable for the Tamminen children, because Hanna's father regarded the accumulation of cultural capital as a joint effort of the extended family. On 14 May 1900, Yrjö mentioned in his diary that the grandfather was eager to help his grandchildren, even if it meant 'giving away [his] last pair of trousers' (Diary of Yrjö Tamminen). In addition, the arrangement was convenient, because the children were able to remain within their old network and the system of mutual help. For example, according to the diaries, Mrs Krogerus kept an eye on the Tamminen children, even though she, too, had become a widow in 1890 (Mikkelin Sanomat 1890).

It can also be argued that as the children were raised as members of the community they had been born into, and as the community was familiar with their tragic background, it was easy for them to get a free place at the grammar school at some point during their studies. Yrjö Tamminen's diary entries indicate that both Yrjö and his younger brother were granted free years at their grammar school, albeit not simultaneously. Moreover, Yrjö was allowed to borrow school books from the school library.

Nevertheless, both Hanna and her children suffered from their separation, because despite the good will of the children's grandfather, conditions in his household were hardly favourable. Hanna's mother had died in 1895 (Saimaa 1895), and, according to the diaries of Yrjö Tamminen, the household was being managed by a young and arrogant maidservant. Moreover, the children's grandfather had developed a drinking habit. Although the diaries do not depict the grandfather as being violent, the home environment was chaotic and stressful. That no attempts were made to change the existing arrangement points to the limited economic means of the family, but also to the fact that getting a grammar school education was prioritised over temporary hardships. It was not until 1899, 
when the maidservant fell pregnant and became a walking indication of the decadence that prevailed in the house, that Hanna Tamminen felt compelled to place her children in a boarding house.

In the end, the Tamminen family managed to preserve and even increase their cultural and social capital by investing in a grammar school education. The three children found a place among the rising intelligentsia by graduating from grammar school and continuing their studies at college or university. Yrjö Tamminen took a degree in law in 1909 (Student Register 1817-1901), and was appointed treasurer of the National Board of Railways in 1919. He retired as the Chief Inspector of National Board of Railways. His brother, in turn, became an agronomist in 1906 and served as the City Agronomist of Helsinki from 1922 onwards. Both sons married and started a family. Their sister became an elementary school teacher in 1905. At that point, Hanna Tamminen resigned from her post at Janakkala workhouse and moved to live with her daughter (MLGSA 1954, 323; MLSA 1948, 478; Tamminen 2007a-b). ${ }^{11}$

\section{Education as an internalised value}

This second section discusses how cultural and social capital were interlinked on an ideological level in Yrjö Tamminen's diary entries. It is suggested that in his world-view, education was bound to the concept of self-improvement and to Fennoman ideology. Overall, his perception of education highlights the fact that although the offspring of the rising intelligentsia mostly went to the same schools as the children of the old elite, their goals stemmed from a different basis.

Judging from Yrjö's diaries, he and his siblings followed the example set by their parents: in order to associate themselves with the network of the rising intelligentsia, they made a distinction in relation to both the common people and the old elite. In Yrjö's mind, making a distinction vis-à-vis the common people was easy: while he was educated, they were not. On the whole, the grammar school students were encouraged to distinguish themselves from the uneducated townspeople. On 27 September 1898, Yrjö remarked on the fact that the principal of his sister's school had forbidden her students from promenading in the city park in the evenings, because it was considered inappropriate that they would be 'fighting over parks and park benches with artisans and maidservants' (Diary of Yrjö Tamminen). 
The way Yrjö made a distinction with regard to the rural people in Janakkala, where he spent his summer holidays, resembles the relationship between the rising intelligentsia and the uneducated rural people in general: the members of the rising intelligentsia were to both investigate and educate the rural people (Ollila 1993, 48. See also Rojola 2009, 31-34; Vares 2005, 273). For Yrjö, the rural population functioned as a source of earthy proverbs and curious habits, which he registered in his diary. However, for the most part he found the rural atmosphere and especially the workhouse mentally unchallenging. On 25 June 1899, he reproached himself for not having 'a single noble thought' in his head, and added in a laconic tone: 'Then again, where could you get those in a place like this?' (Diary of Yrjö Tamminen).

Making a distinction with regard to the old elite was more complicated. On the one hand, Yrjö was prone to associating with his socio-economically superior schoolmates, such the son of the principal. While in Janakkala, he only socialised with the more prominent local families and their summer guests. On 1 June 1899, he even confessed to his diary that he had not greeted a friend of his sister in the street because the girl 'did not belong to the elite' (Diary of Yrjö Tamminen). On the other hand, it is important to note that his remark was indeed a confession. It seems that deep in his heart, he did not want to imitate the old elite in its arrogance, but to become a more noble-minded individual instead. Thus, the distinction between him and the members of the old elite was not only a cold fact determined by the socio-economic reality, but also a deliberate choice made by Yrjö himself.

A commitment to self-improvement is one of the recurrent themes in Yrjö's diary. ${ }^{12}$ The constant pursuit for self-improvement was typical of the rising intelligentsia: while education was to be their route to prominent positions in society, self-improvement was to be their way of making sure that they would constitute a morally superior new elite. Thus, education and the pursuit for self-improvement became inseparably intertwined (Leskelä-Kärki 2006, 292; Ollila 1998, 38, 70-71, 76-77, 230; Vares 2005, 18, 41, 93). In Yrjö's case, the commitment to self-improvement was strongly encouraged by his teachers. According to an entry written on 9 June 1898, one of Yrjö's teachers had suggested that every student should set himself 'the ultimate goal of becoming a good person' (Diary of Yrjö Tamminen).

However, Yrjö found it difficult to be good and just, especially in the little everyday trials. 'I have such a weak character,' he complained in his diary on 2 June 1897, 'I cannot resist temptations like a good soldier but have to run from them. [--] I once got a good piece of advice though: I should never 
permit myself anything I really want' (Diary of Yrjö Tamminen). According to Yrjö, his weak character manifested itself, for example, in his constant craving for sweets, the fact that he had tried his grandfather's cigarettes a couple of times, the crushes he had on different girls, his habit of swearing, his occasional gossiping and idle talk, writing school essays for his friends, laziness, and the bouts of vanity he saw himself as prone to. Yrjö's harsh self-assessment gives a good impression of the way a member of the rising intelligentsia was expected to control himself (or herself) in order to be qualified as a morally superior model citizen.

It seems that Yrjö's pursuits for self-improvement were constantly challenged by the conditions in his grandfather's household. The juxtaposition is illustrated in a diary entry an upset Yrjö wrote on 15 October 1898, after coming home from an uplifting student meeting to find his grandfather and the old man's comrades completely intoxicated. He stated, 'The noble causes we discuss at the fraternity meetings will get me nowhere, because my home life is so miserable.' Yrjö set himself mentally apart from his grandfather: 'I have got into such beautiful company: there are drunkards, brawlers, mockers, mad people [...], atheists, and so forth. It is a small wonder I have managed to remain to some extent incorrupt as I am now' (Diary of Yrjö Tamminen). Like many others among the rising intelligentsia, Yrjö and his sister became active supporters of the temperance movement (Jämbäck 2008).

The diary entries suggest that the morality of the young Yrjö Tamminen was also insulted by the reckless behaviour of his grandfather's maidservant. Yrjö could not find sympathy for the pregnant woman or for morally questionable women in general. His uncompromising attitude stemmed from his commitment to the ideal of premarital chastity. The rising intelligentsia promoted this ideal as a morally sound alternative to the relative sexual morality favoured by both the common people and the old elite (Häggman 1994, 187; Markkola 2014; Melkas 2009, 111; Nieminen 1951, 74, 82; Rajainen 1973, 96-97; Siltala 1999, 560). On 2 November 1899, Yrjö wrote in his diary that he wanted to keep his 'first love pure', and had therefore refrained from kissing his long-time infatuation despite the romantic setting of a promenade in a forest. His choice, alongside his decision to avoid alcohol, indicates that he was prepared to live up to his ideals.

In Yrjö's diary entries, getting a grammar school education and engaging in self-improvement were linked with Fennoman ideology. This, too, was typical of the members of the rising intelligentsia, who considered themselves the torchbearers for the entire Finnish nation. Fennoman ideology was 
rooted into the curricula of the Finnish-speaking grammar schools (Vares 2005, 65), such as the ones in Mikkeli. Yrjö, however, was a second- (if not third-) generation Fennoman. His father Juho Tamminen was one of the spokesmen who had campaigned successfully for Finnish grammar school education in Mikkeli in the late 1870s and early 1880s. Moreover, Juho's appointments as the city treasurer and as the secretary of the City Council were linked with the growing Fennoman influence in the city administration (Kuujo 1971; Mikkeli City Council 1879-1889).

Whereas the Fennoman movement had provided Yrjö's father with new opportunities for gathering social capital as a man of the cause, ${ }^{13}$ Yrjö himself associated Fennoman ideology with sacrifice and duty. His perception was probably influenced by the tense political situation of the late 1890s. In February 1899, Finland was subjected to a Russification campaign launched by Czar Nicholas II of Russia. The Fennomans opposed the campaign strongly as a threat to the autonomy of Finland and to the future of the Finnish nation. Although Yrjö self-censored his writings on daily politics, it is clear that he followed the political situation keenly. He also joined the ranks of the half a million Finns (circa 20 per cent of the total population) who signed the petition that was to be brought to the Czar in order to convince him to cancel the Russification campaign (Great Petition 1899).

The thought of patriotic sacrifice was most evidently present in a diary entry Yrjö wrote on 14 March 1899. He described the beauty of the Finnish rural landscape: 'The wind whispered in the trees above me, and a spring-like cuckoo called down into the valley. Should someone have asked me then if I would give my life for all this, I would have answered without hesitation: "Yes, I would" , (Diary of Yrjö Tamminen).

The thought of sacrifice was also connected to Yrjö's understanding of the more mundane duties of a young man, as revealed in an entry he wrote on 5 March 1899:

I would like to accomplish something great, something magnificent that would bring glory to my fatherland. ... However, should every man become 'great', we would be lacking 'the small', who are equally important. Finland now needs the help and vigour of all her sons. ... If everyone fulfils his duty conscientiously, without pursuing personal glory, if everyone sacrifices himself for the fatherland and the people, Finland will be fortunate and our small nation may expect a good future.' (Diary of Yrjö Tamminen) 
It seems that at the age of seventeen, Yrjö Tamminen had come to understand that even the rising intelligentsia could be divided into a vanguard and a larger bulk of more ordinary actors.

The diaries of Yrjö Tamminen suggest that he had dreams of a career as a journalist. At the same time, Yrjö knew that his mother had another plan for him: after graduating from grammar school, Yrjö was to head for a career on the railways. However, he was not to become a regular worker, but an official. The diary entries indicate that Hanna Tamminen had discussed her son's future with a treasurer whose identity is not revealed. According to her, the treasurer had emphasised the importance of taking a law degree at university before entering the railways. As such, Yrjö would have opportunities for advancement within the institution, which would eventually secure his social standing among the rising intelligentsia. As mentioned earlier, Hanna turned out to be right.

On the one hand, it seems that Yrjö himself was not particularly interested in the railways. On the other hand, he knew that it was his duty to relatively quickly acquire a regular income to be able to help his mother and siblings financially. Sacrifices had been made for his education - and in the end, he too was willing to sacrifice his private dream of becoming a journalist: he started making concrete plans on how to proceed in the railways. In a diary entry written on 7 January 1900, he already pictured himself as a Fennoman stationmaster: 'Many years from now, I will have become a station master. [My office] will resemble a Finnish farmhouse living room, something like the one described in Maila Talvio's novel Kaksi rakkautta with the addition of having a specific bookcase filled with exclusively Finnish literature' (Diary of Yrjö Tamminen).

\section{Conclusions}

In the life of the Tamminen family, 1878-1887 marked a relatively steady period during which the family integrated into Mikkeli's middle-class society. The early years were characterised by the establishment of central family values, such as the Fennoman ideology, and also by the emergence of a shared goal - namely, social status among the rising intelligentsia. The Tamminens' prospects were changed by the death of the family breadwinner in 1887 . Hanna became the sole supporter of her three minor children. From 1887 to 1900 , she fought to preserve the central family values and to meet the shared goal in spite of the family's reduced economic circumstances. Yrjö's diary entries show that both the above-mentioned family values and the shared goal were carried on to the next 
generation. In the end, the Tamminen children were able to successfully claim a place among the rising intelligentsia.

The Tamminen case shows that the Finnish middle class of the time could be divided into at least two sub-classes. For the Tamminens, upward social mobility meant mobility within the middle class. Because the Tamminens were not remarkably wealthy, their social ascent was not so much bound to economic capital as to cultural and social capital - namely, education and networking. For them, the grammar school was an institution that provided the youth with the practical means to enter upper middle-class professions and the social network required for a successful career. The Tamminen family invested in education both by campaigning for Finnish grammar schools in general, and by enabling their children's entrance to grammar school, regardless of the family's economic circumstances.

Pierre Bourdieu's notion of cultural distinctions as a means of constructing social status is supported by the Tamminen case. The Tamminens constructed a social status among the rising intelligentsia by making distinctions concerning both the uneducated common people and the old elite. Because the old elite remained out of reach for the Tamminens, they had to identify themselves with the new elite that was furthering the Fennoman ideology.

In Yrjö's case, Fennoman sympathies intertwined with a sense of sacrifice and duty. He constantly strove to become a better person. In the process, he made sharp distinctions with other people who did not take self-improvement seriously - to the uneducated common people because they did not know better, and to the members of the old elite because they simply did not care. While it is obvious that Yrjö did not always succeed in his ambitious endeavours, the ideals he communicated in his diaries reveal his affiliation with the rising intelligentsia.

Furthermore, the Tamminen case shows how individual lives intertwine in families, forming networks of lives. The choices of individual family members are influenced by other family members and their respective choices. Moreover, the Tamminen case indicates that a close-knit network such as a family may give rise to shared goals that guide or restrict the individual family members' choices. As mentioned above, social status among the rising intelligentsia became one of the guiding principles for the Tamminens. After the death of her husband, Hanna chose to become a workhouse matron because public-sector social work provided her with the socially accepted means to support her 
children and finance their grammar school education. Yrjö's decision to choose a future on the railways over a literary career reflects his understanding of his role as a co-supporter of the family. On the other hand, the fact that he was bound to pursuing a law degree indicates that he was hoping for a career as an upper middle-class railways official.

Individual life choices are also influenced by the time and the place in which the individuals live. The careers of Hanna Tamminen and her husband in particular were made possible by the growth of the public sector at the end of the nineteenth century. Because the qualifications for the new openings were rather unspecified initially, and because the educational background of the Finnish population in general was weak, people with some amount of education were usually able to seize these new positions. Juho Tamminen in particular is an example of 'a middle-class general worker' who never finished grammar school but held several posts as an official. His meandering path is contrasted by the relatively straightforward career of his son on the railroads. While both men eventually became treasurers, the level of professionalisation required in their posts was clearly different. This, in turn, points to the modernisation of Finland.

\section{Archival Material}

Census List. 1887. Mikkeli City Census Lists. Mikkeli City Archives, Mikkeli.

Census List. 1888. Mikkeli City Census Lists. Mikkeli City Archives, Mikkeli.

Estate Inventory Deed. 1887. The estate inventory deed of Juho Tamminen. August 13. The National Archives of Finland, Mikkeli.

Diary of Yrjö Tamminen. 1897-1900. Tamminen Family Private Archives, Helsinki.

Great Petition. 1899. Mikkeli City. The National Archives of Finland, Helsinki. http://digi.narc.fi.

Janakkala Communion Book. 1896-1905. Janakkala Parish Archives. 143 I Aa:8. The National Archives of Finland, Hämeenlinna. 
Janakkala Parish Council. 1896. The record of parish council meeting. September 28. Janakkala Communal Archives, Janakkala.

Jyväskylä Birth Records. 1796-1832. Jyväskylä Parish Archives. I C:2. The National Archives of Finland, Jyväskylä.

Luhanka Children's Book. 1839-1857. Luhanka Parish Archives. I Ab:5. The National Archives of Finland, Jyväskylä.

Mikkeli Birth Records. 1880-1889. Mikkeli Parish Archives. I C:10. The National Archives of Finland, Mikkeli.

Mikkeli City Council. 1879-1889. The records of city council meetings. Mikkeli City Council Archives. Ca:2-Ca:5. Mikkeli City Archives, Mikkeli.

Mikkeli City Council. 1880. The record of city council meeting. June 21. Mikkeli City Council Archives. Ca:5. Mikkeli City Archives, Mikkeli.

Mikkeli City Council. 1881. The record of city council meeting. January 9. Mikkeli City Council Archives. Ca:5. Mikkeli City Archives, Mikkeli.

Mikkeli City Council. 1884. The record of city council meeting. January 14. Mikkeli City Council Archives. Ca:4. Mikkeli City Archives, Mikkeli.

Mikkeli City Council. 1887a. The record of city council meeting. June 1. Mikkeli City Council Archives. Ca:5. Mikkeli City Archives, Mikkeli.

Mikkeli City Council. 1887b. The record of city council meeting. July 22. Mikkeli City Council Archives. Ca:5. Mikkeli City Archives, Mikkeli.

Mikkeli City Council. 1889. The record of city council meeting. April 11. Mikkeli City Council Archives. Ca:5. Mikkeli City Archives, Mikkeli. 
Mikkeli City Treasury. 1881a. The record of city treasury members' meeting. June 21. Mikkeli City Treasury Archives. IV 5, Ca:1. Mikkeli City Archives, Mikkeli.

Mikkeli City Treasury. 1881b. The record of city treasury members' meeting. November 21. Mikkeli City Treasury Archives. IV 5, Ca:1. Mikkeli City Archives, Mikkeli.

Mikkeli City Treasury. 1882. The record of city treasury members' meeting. May 2. Mikkeli City Treasury Archives. IV 5, Ca:1. Mikkeli City Archives, Mikkeli.

Mikkeli Communion Book. 1859-1869. Mikkeli Parish Archives. I Aa:27. The National Archives of Finland, Mikkeli.

Mikkeli Communion Book. 1880-1889. Mikkeli Parish Archives. I Aa:33. The National Archives of Finland, Mikkeli.

Student Register. 1817-1901. University of Helsinki Archives, Helsinki. http://www.helsinki.fi/keskusarkisto/matrikkelit/yo_matrikkelit.htm.

Tamminen, Pirkko. 2007a. In discussion with the author. June 12.

Tamminen, Pirkko. 2007b. In discussion with the author. October 20.

\section{References}

Ala, Juha. 1999. Suomi-neito ja suojelusikä: Sortovuosien psykohistoria. Helsinki: Gaudeamus.

Alapuro, Risto. 1994. Suomen synty paikallisena ilmiönä 1890-1933. Helsinki: Hanki ja Jää.

Annola, Johanna. 2011. Äiti, emäntä, virkanainen vartija: Köyhäintalojen johtajattaret ja yhteiskunnallinen äitiys, 1880-1918. Helsinki: Finnish Literature Society. 
Annola, Johanna. 2013. "Valtiovalta köyhäintalon johtajan ammatin rakentajana 1880-1921.” Janus 21 (3): 192-205.

Annola, Johanna. 2016. “Out of Poverty: The Ahrenberg Siblings, 1860-1920.” Journal of Finnish Studies 20 (1): 132-163.

Annola, Johanna. Forthcoming. "Female Biographies, Social Service and Social Mobility." In Gender, History, Futures: Report from the XI Nordic Women's and Gender History Conference, Stockholm, Sweden, August 19-21 2015, edited by Daniel Nyström and Johanna Overud, 40-49. Umeå: SKOGH.

Antell, Alina. 1905. Program öfver Antellska privata svenska fruntimmersskolan under läseåret 1903-1904: Återblick på dess 50 åriga verksamhet från år 1854-1904. Mikkeli: Kirjapaino Saimaa.

Blackbourn, David. 1991. “The German Bourgeoisie: An Introduction.” In Essays on the Social History of the German Middle Class from the Late Eighteenth to the Early Twentieth Century, edited by David Blackbourn and Richard J. Evans, 1-45. New York: Routledge.

Bloom, Lynn Z. 1996. “'I Write for Myself and Stangers': Private Diaries as Public Documents.” In Inscribing the Daily: Critical Essays on Women's Diaries, edited by Suzanne L. Bunkers and Cynthia A. Huff, 23-37. Amherst: University of Massachusetts Press.

Bourdieu, Pierre. 1984. Distinction: A Social Critique of the Judgement of Taste. Cambridge: Harvard University Press.

Dribe, Martin, and Christer Lundh. 2010. "Marriage Choices and Social Reproduction: The Interrelationships Between Partner Selection and Intergenerational Socioeconomic Mobility in 19thcentury Sweden.” Demographic Research 22: 347-382. doi:10.4054/DemRes.2010.22.14.

Dribe, Martin, and Patrick Svensson. 2008. "Social Mobility in Nineteenth Century Rural Sweden: A Micro Level Analysis." Scandinavian Economic History Review 56:122-141. doi: 10.1080/03585520802137194. 
Folkwännen. 1887. “Om det sorgliga själfmordet i St. Michel.” July 25. Digital Newspaper Collection. National Library of Finland. digi.kansalliskirjasto.fi.

FWA (Finnish Women’s Association). 1894. Kalenteri Suomen naisten työstä. Helsinki: FWA.

Ginsberg, Elaine. 1996. "The Politics of Passing." In Passing and the Fictions of Identity, edited by Elaine Ginsberg, 1-18. Durham \& London: Duke University Press.

Haapala, Pertti. 1995. Kun yhteiskunta hajosi: Suomi 1914-1920. Helsinki: Painatuskeskus.

Hakosalo, Heini. 2014. “'Our Life Work': Professional Women and Christian Values in Early Twentieth Century Finland." In Finnish Women Making Religion: Between Ancestors and Angels, edited by Terhi Utriainen and Päivi Salmesvuori, 83-102. New York: Palgrave Mcmillan.

Helsingfors Dagblad. 1881. "Stadskamererare och dermed förenade kronokassörsbefattningen i Kotka.” March 8. Digital Newspaper Collection. National Library of Finland. digi.kansalliskirjasto.fi.

Häggman, Kai. 1994. Perheen vuosisata: Perheen ihanne ja sivistyneistön elämäntapa 1800-luvun Suomessa. Helsinki: Finnish Historical Society.

Häkkinen, Antti. 2014. "Vuosisadat, sukupolvet, elämänkulut: Merkitysten analysoimisesta toiminnan tutkimiseen." In Työväestö ja hyvinvointi, edited by Matti Hannikainen, 13-35. Helsinki: Finnish Society for Labour History.

Hämäläinen. 1881. "Valtuusmiesten sihtierin virka." February 2. Digital Newspaper Collection. National Library of Finland. digi.kansalliskirjasto.fi.

Jalava, Marja. 2005. Minä ja maailmanhenki: Moderni subjekti kristillis-idealistisessa kansallisuusajattelussa ja Rolf Lagerborgin kulttuuriradikalismissa, 1800-1914. Helsinki: Finnish Literature Society.

JLSA (Jyväskylä Lyceum Students’ Association). 1983. Jyväskylän lyseo 1858-1983. Jyväskylä: JLSA. 
Juvonen, Tuula. 1995. Sukupuoli ja halu Hilda Käkikosken kirjeenvaihdossa ja päiväkirjoissa. Helsinki: The Ministry of Health.

Jämbäck, Eija. 2008. Naiset valistuksen virittäjinä: Suomalaisen Konkordia-liiton rahastolahjoittajien ja kunniajäsenten elämäkerrasto. Helsinki: Concordia Foundation.

Kocka, Jürgen. 1993. "The European Pattern and the German Case." In Bourgeois Society in Nineteenth-Century Europe, edited by Jürgen Kocka and Allan Mitchell, 3-39. Oxford: Berg.

Kuujo, Erkki. 1971. Entisajan Mikkeli: Mikkelin kaupungin vaiheita 1838-1917. Mikkeli: LänsiSavon Kirjapaino.

Leskelä-Kärki, Maarit. 2006. Kirjoittaen maailmassa: Krohnin sisaret ja kirjallinen elämä. Helsinki: Finnish Literature Society.

Maas, Ineke, and Marco H. D. van Leeuwen. 2002. "Industrialization and Intergenerational Mobility in Sweden.” Acta Sociologica 45: 179-194.

Makkonen, Anna. 1996. Sinulle: Romaani, joka ei uskalla sanoa nimeään tai Nainen, kapina, kirjoitus ja historia eli mitä tapahtui, kun tämän kirjan tekijä sai käsiinsä erään päiväkirjan vuodelta 1905. Helsinki: Finnish Literature Society.

Markkola, Pirjo. 1994. Työläiskodin synty: Tamperelaiset työläisperheet ja yhteiskunnallinen kysymys 1870-luvulta 1910-luvulle. Helsinki: Finnish Historical Society.

Markkola, Pirjo. 2014. "Moraalin miehet: Mitä prostituution sääntely kertoo mieheydestä?” In Näkymätön sukupuoli: Mieheyden pitkä historia, edited by Pirjo Markkola, Ann-Catrin Östman, and Marko Lamberg, 134-158. Tampere: Vastapaino.

Melkas, Kukku. 2009. "Palvelustyttö sivistyneistön peilinä.” In Läpikulkuihmisiä: Muotoiluja kansallisuudesta ja sivistyksestä 1900-luvun alun Suomessa, edited by Kukku Melkas, Heidi Grönstrand, and Kati Launis, 107-134. Helsinki: Finnish Literature Society. 
Mikkelin Sanomat. 1886. "Mikkelin läänin säästöpankin vuosikokouksessa.” January 14. Digital Newspaper Collection. National Library of Finland. digi.kansalliskirjasto.fi.

Mikkelin Sanomat. 1887. "Hyyrättäwänä.” December 1. Digital Newspaper Collection. National Library of Finland. digi.kansalliskirjasto.fi.

Mikkelin Sanomat. 1888a. "Kassavaillinki.” May 12. Digital Newspaper Collection. National Library of Finland. digi.kansalliskirjasto.fi.

Mikkelin Sanomat. 1888b. An advertisement by Hanna Tamminen. October 17. Digital Newspaper Collection. National Library of Finland. digi.kansalliskirjasto.fi.

Mikkelin Sanomat. 1889a. "Kuulutus.” January 5. Digital Newspaper Collection. National Library of Finland. digi.kansalliskirjasto.fi.

Mikkelin Sanomat. 1889b. "Jäähyväis pidot." January 9. Digital Newspaper Collection. National Library of Finland. digi.kansalliskirjasto.fi.

Mikkelin Sanomat. 1889c. "Talonkauppa." February 13. Digital Newspaper Collection. National Library of Finland. digi.kansalliskirjasto.fi.

Mikkelin Sanomat. 1890. The obituary of Magnus Wilhelm Krogerus. February 15. Digital Newspaper Collection. National Library of Finland. digi.kansalliskirjasto.fi.

MLGSA (Mikkeli Lyceum for Girls Students’ Association). 1954. Mikkelin tyttölyseo 1879-1954. Mikkeli: MLGSA.

MLSA (Mikkeli Lyceum Students' Association). 1948. Mikkelin lyseo 1872-1847. Helsinki: Kustannusosakeyhtiö Karhu. 
Moi, Toril. 1999. “Appropriating Bourdieu: Feminist Theory and Pierre Bourdieu's Sociology of Culture." In What is a Woman? And Other Essays, edited by Toril Moi, 264-299. New York: Oxford University Press.

Moring, Beatrice. 2008. "Widows, Children and Assistance from Society in Urban Northern Europe, 1890-1910." The History of the Family 13(1): 105-117. doi: 10.1016/j.hisfam.2008.01.005.

Nieminen, Armas. 1951. Taistelu sukupuolimoraalista. Porvoo: WSOY.

Ollila, Anne. 1993. Suomen kotien päivä valkenee: Marttajärjestö suomalaisessa yhteiskunnassa vuoteen 1939. Helsinki: Finnish Historical Society.

Ollila, Anne. 1998. Jalo velvollisuus: Virkanaisena 1800-luvun lopun Suomessa. Helsinki: Finnish Literature Society.

Ollila, Anne. 2000. Aika ja elämä: Aikakäsitys 1800-luvun lopussa. Helsinki: Finnish Literature Society.

Pellervo. 1881a. An advertisement by Juho Tamminen. October 29. Digital Newspaper Collection. National Library of Finland. digi.kansalliskirjasto.fi.

Pellervo. 1881b. "Kuulutus." November 26. Digital Newspaper Collection. National Library of Finland. digi.kansalliskirjasto.fi.

Pellervo. 1882a. An advertisement by Juho Tamminen. March 18. Digital Newspaper Collection. National Library of Finland. digi.kansalliskirjasto.fi.

Pellervo. 1882b. "Ilmoitus." April 8. Digital Newspaper Collection. National Library of Finland. digi.kansalliskirjasto.fi.

Pellervo. 1882c. “Talonkauppa.” July 22. Digital Newspaper Collection. National Library of Finland. digi.kansalliskirjasto.fi. 
Pellervo. 1883. "Arpajaiset." February 15. Digital Newspaper Collection. National Library of Finland. digi.kansalliskirjasto.fi.

Rajainen, Maija. 1973. Naisliike ja sukupuolimoraali. Helsinki: Finnish Society of Church History.

Renfrow, Daniel. 2004. “A Cartography of Passing in Everyday Life.” Symbolic Interaction 27(4): 485-506. doi: 10.1525/si.2004.27.4.485.

Rojola, Lea. 2009. "Sivistyksen ihanuus ja kurjuus: suomalaisen nousukkaan tarina." In Läpikulkuihmisiä: Muotoiluja kansallisuudesta ja sivistyksestä 1900-luvun alun Suomessa, edited by Kukku Melkas, Heidi Grönstrand and Kati Launis, 10-38. Helsinki: Finnish Literature Society.

Roos, Jeja-Pekka. 1987. "Pelin säännöt: Intellektuellit, luokat ja kieli." In Pierre Bourdieu, Sosiologian kysymyksiä, 7-28. Translated by Jeja-Pekka Roos. Tampere: Vastapaino.

Saimaa. 1895. The obituary of Fredrika Hagelin. April 16. Digital Newspaper Collection. National Library of Finland. digi.kansalliskirjasto.fi.

Siltala, Juha. 1999. Valkoisen äidin pojat: Siveellisyys ja sen varjot kansallisessa projektissa. Helsinki: Otava.

Stenius, Henrik. 1987. Frivilligt jämligt samfällt: Föreningsväsendets utveckling i Finland fram till 1900-talets början med speciell hänsyn till massorganisationsprincipens genombrott. Helsinki: Society of Swedish Literature in Finland.

Sulkunen, Irma. 1995. Mandi Granfelt ja kutsumusten ristiriita. Helsinki: Hanki ja jää.

Sulkunen, Irma. 2004. Suomalaisen Kirjallisuuden Seura 1831-1892. Helsinki: Finnish Literature Society.

Suomalainen Wirallinen Lehti. 1884. "Mikkelin wapaehtoinen palokunta." August 7. Digital Newspaper Collection. National Library of Finland. digi.kansalliskirjasto.fi. 
Ulvros, Eva Helen. 1996. Fruar och mamseller: Kvinnor inom sydsvensk borgerlighet 1790-1870. Lund: Historiska media.

Vainio-Korhonen, Kirsi. 2012. Sofie Munsterjelmin aika: Aatelisnaisia ja upseereita 1800-luvun Suomessa. Helsinki: Finnish Literature Society.

Vares, Vesa. 2005. Helmi Krohn 1871-1913: Naisen velvollisuusetiikka ja yksilön ratkaisu. Helsinki: Helsinki University Press.

Vilkuna, Kustaa H. J. 1992. "Kunnallishallinto kuntakokouskaudella vuosina 1868-1918.” In Mikkelin maalaiskunnan kirja, edited byTeppo Vihola, 235-254. Jyväskylä, Mikkeli Parish.

\footnotetext{
${ }^{1}$ For the benefits of choosing a partner with a similar social status, see Häkkinen 2014, 29.

${ }^{2}$ Because there were no competence requirements for attorneys until 1898, Juho Tamminen could present himself as one even though he did not have a degree in law.

${ }^{3}$ For 'passing' as the ability of an individual to be seen as a member of a category other than his or her own, see Ginsberg 1996; Renfrow 2004.

${ }^{4}$ For ordinary people as research subjects, see Annola forthcoming; Vainio-Korhonen 2012, 270-271, 277. For the positive and negative connotations attached to the concept of social climbing, see Rojola 2009.

${ }^{5}$ The discussions between Pirkko Tamminen and the present author took place in 2004-2013. While the author's thanks can no longer reach Ms Tamminen, she wishes to express her gratitude to the surviving members of the family for their support and cooperation.

${ }^{6}$ In the $1880 \mathrm{~s}$, Mikkeli was a small inland city of under 2,000 inhabitants. The county administration of Mikkeli Province, a garrison, and three grammar schools were located in the city. From the contemporaries' point of view, the socio-economic division between the Swedish-speaking administrative elite and the Finnish-speaking majority was sharp (Kuujo 1971, 296-303, 374, 379).

${ }^{7}$ For marriage as a means of integrating into a local network, see Annola 2016, 143-145; Dribe and Lundh 2010, 374; Dribe and Svensson 2008, 128-129, 140.

${ }^{8}$ The other members included the Mayor's wife, Fanny Alopaeus, and the owners of the Antell School for Girls, Alexandra and Alina Antell. While voluntary fire brigades were non-profit associations that sought to unify all people for the public good, they were nevertheless often managed by officials, entrepreneurs, and other prominent men. Respectively, their wives were expected to engage themselves into supportive activities. According to Risto Alapuro $(1994,74)$ and Henrik Stenius (1987, 234- 267) a high social status usually equalled a high status in the fire brigade, and vice versa.

${ }^{9}$ For the networking and the mutual aid of aspiring men, see Ollila 1998, 195.

${ }^{10}$ Hanna's salary was decent even in comparison with annual salaries in other typical middle-class female occupations in 1897. Nurses: 200-600 Finnish marks plus keep; rural midwives: 400-800 Finnish marks, no keep; rural female workhouse directors: 240-500 Finnish marks plus free quarters, heating, and lighting; rural female primary school teachers: 600 Finnish marks plus free quarters, heating, and lighting; female teachers in rural ambulatory schools: 200450 Finnish marks, no keep (FWA 1894, 175, 179, 188, 203, 207-208).

${ }^{11}$ It was typical for the contemporaries among both the rising intelligentsia and the working class to assume that the daughter (i.e. not the sons) of the family would be the one taking care of her ageing parents (Markkola 1994, 111; Moring 2008, 111; Ollila 1998, 25-26, 61).

${ }^{12}$ For diary as a vehicle for (religious) self-education, see also Hakosalo 2014.
} 
J Annola, A Place in the Sun? (post print)

${ }^{13}$ For Fennoman ideology as a legitimation for personal aspirations, see Ollila 1998, 195, 205; Leskelä-Kärki 2006, 625. 